\title{
A Study on the Possible Causes of China's Trade Deficits with South Korea after Their Establishment of Diplomatic Relations
}

\author{
Lili Pan \\ Department of Korean Language, Qufu Normal University \\ Rizhao 276826, Shandong, China \\ E-mail: panlili0622@yahoo.com.cn
}

\begin{abstract}
The trend of globalization since the early 1990s has had a profound impact on trade relations between China and South Korea. It affected these two countries in positive ways, and brought Sino-Korean trade to its highest level since the establishment of diplomatic relations on August 24, 1992. Sino-Korean trade, as the scale of its growth and development accelerated, was also exposed to and encountered various problems. Among those problems, the most important and urgent problem to be solved was that in Sino-Korea trade, the deficit on the China side has continued to increase. This paper focuses on analyzing the causes of this problem.
\end{abstract}

Keywords: Sino-Korean trade, Trade deficits, Trade balance, Win-Win situation

\section{Introduction}

There are more and more studies on Sino-Korean relations in recent years especially since 1992. However, most of those existing studies predominantly document the Sino-Korean trade relations from the standpoint of South Korea, and focus on how South Korean enterprises increase market share in China. This paper tries to discuss the Sino-Korean trade relations from the standpoint of China. From China's stand, it will look into the exposed problems particularly focusing on China's increasing trade deficit in Sino-Korean trade relations, and concentrate on finding its possible causes.

\section{A Review of Trade Balance between China and South Korea}

The relationship between merchandise imports and exports is referred to as the balance of trade, or trade balance. If a country exports more goods than it imports, it has a favorable balance of trade; if it imports more goods than it exports, as China has done in Sino-Korean trade during the last 16 years, it has an unfavorable balance of trade, according to the statistical data, as shown in figure 1 . Usually a country that has a negative balance of trade also has a negative balance of payments.

\section{Insert Figure 1 Here}

The actual figures in the last column of table 1 show that balance in China's trade with South Korea recorded deficits of USD 1.22 billion in 1993, USD 5.66 billion in 2000, and USD 4.89 billion in 2001. In 2002 and 2003, China recorded trade deficits of about 6.35 billion dollars and 23 billion dollars in its trade with South Korea. The trade deficits reached a peak of 47.7 billion dollars in 2007. It decreased to 38.2 billion dollars until 2008.

From 1993 total accumulated surplus in Korea's trade with China was more than that in its trade with USA and with Japan, it shows how important China is for the Korean economy, and also shows how the imbalance the Sino-Korea trade is.

\section{Insert Table 1 Here}

\section{Causes Analysis of China's Increasing Trade Deficit with South Korea}

Sino-Korean trade has made noticeable development since 1992, going from nothing to something, from small scale to big scale trading. As the scale of Sino-Korean trade growth and development accelerated, it also became exposed to and 
encountered various problems.

Among these problems, the most important and urgent problem to be solved was that in Sino-Korean trade, the loss of the Chinese side has continued to increase since 1993. This increasing trade deficit with China led trade disequilibrium to be one of the main problems in bilateral economic cooperation.

It is hard to avoid the trade deficit in Sino-Korea trade. China's increasing trade deficit with South Korea will bring a negative influence on China's economy, especially unfavorable to the healthy development of bilateral trade. Now let's analyze China's increasing trade deficits problem in Sino-Korean trade relation.

\subsection{Influence of the Asian Financial Crisis}

The Asian financial crisis in South Korea broke out in August 1997, with the country's currency greatly depreciating. There were sharp drops in Korean current prices of stocks at that time. All of that made the domestic economy of South Korea threw in a state of disarray. Under the situation, Korean enterprises couldn't do export/import business as usual. On the other hand, China's "no depreciation" policy increased export costs relatively. Korean enterprises began to cut orders for Chinese down. The result was that exportation from China to South Korea decreased at a large scale.

In order to raise foreign exchange reserve, the Korean government increased exportation taking advantage of Korean currency's depreciation. Trade surplus in Korea grew with a small favorable balance, and it became larger and larger. China, the biggest export market for South Korea, was sure to be influenced by the wave of Korea's enlarging exportation. It brought the disequilibrium in Sino-Korea trade into a tense situation.

\subsection{Influence of Structural Fluctuation of Export and Import Commodities}

On the aspect of export and import commodity structure, China mainly exported primary products or low tech-, low value-added products to South Korea, and the exportation was concentrated on the labor-intensive industries, for example, crude materials, agricultural products, mining products, textile and apparel, etc.

On the other hand, South Korea exported technologically intensive and capital intensive products to China, such as chemical industry manufacture, telecommunication equipment, electron and electrical articles, and so on. Even if China exported some electrical articles to South Korea, they were mainly electronic spare parts. This kind of difference was based on technological difference, and was the possible main reason for bilateral trade disequilibrium.

Given the analysis by Qi Zhang (2003), it can be concluded that the structural fluctuation of the above three kinds of commodities \{chemical industry manufactures, articles of plastic rubber or leather and machinery did have a direct influence on the increasing trade deficits on the Chinese side. That is, the structural fluctuation of import and export commodities of Sino-Korean trade acted as the actual and direct cause of increasing Chinese trade deficits in Sino-Korean trade. Structure of import and export commodities of Sino-Korean trade, based on vertical bilateral specialization, was the main factor which accelerated trade imbalance between China and South Korea.

There were many cheap products in the international market after the break out of the Asian financial crisis. China was sure to lose the market share due to the relatively high price of its export commodities. In other words, even if Korea did not suffer the currency crisis, the difference of trade structure would widen the trade balance and enlarge the trade disequilibrium in Sino-Korea trade. Generally speaking, the export and import commodity structure with the characteristic of vertical division was one of the most important causes for China's increasing trade deficit.

\subsection{Influence of Fluctuation on Korean Direct Investment in China}

The characteristic factors of Korean investment in China are reasons for the imbalance of bilateral trade. In order to encourage the development of new industries and speed up the procedure of upgrading the industrial structure, the Korean government took positive policies to encourage labor-intensive industries to invest in overseas. Of course China became the first target country of their investment in that the geographically close location; lower economic development; lower cost of labor resources; and plenty of agricultural, mining resources, etc.

Actually, Korean direct investment in China has exploded since the opening of diplomatic relations in 1992. As China's cheap labor has been a key factor in attracting Korean investors, Korean direct investment has largely focused on the sectors of manufacturing (fiber, costume, electronic and appliance assembling, footwear making, petrol-chemical product, the food and beverage industry), transportation, construction, real estate, and so forth.

Looking at the investment scale, Korean small and medium-size enterprises are leading the Korean investment charge in China. The average size of Korean investment in China was only 1.77 million dollars, as reported by C. Min Han(2000, P10, P23).

Most Korean enterprises in China did the main export and import business (about 70 per cent) in Sino-Korean trade relations. The bilateral trade lacked increasing power due to the above two features, and also lack of the ability to withstand risks. In a word, the increased Korean direct investment in China is supposed to be another factor of increasing China's trade deficits in Sino-Korea trade. 


\subsection{Influence of Change of Average Tariff Rates}

Due to China's high economic growth, geographic proximity and industrial complementary, Sino-Korean trade is expected to record fast growth. The Korea Ministry of Commerce, Industry and Energy predicted that Sino-Korea trade will triple to USD 102.5 billion in 2008, and now it becomes true. Korea's exports to China will continue to increase as China's joining the WTO lowered tariffs for core industries like automobile, chemistry and electronics.

China has already been a member of World Trade Organization since November 2001. According to the statistical data, China's average tariff decreased at a very large scale. Since 2002, the Chinese government has lowered its overall tariff level from 15.3 per cent to 12 per cent, involving about 5300 tariff items. Until the year 2005 , the overall tariff level would be lowered to 10 per cent as committed. It is obvious that there is an important relationship between the decreasing of average customs tariff and the increasing trade deficits on the Chinese side.

\section{Conclusions}

With the fast development of bilateral trade, the problem of China's increasing trade deficits with Korea was exposed and became an important and urgent problem to be solved. According to the analysis of this paper, four main causes for the problem are as follows.

As well as the influence of the Asian Financial Crisis, structural fluctuation of import and export commodities of Sino-Korean trade acted as the actual and direct cause of increase in China's trade deficits to Korea. Besides of the above two reasons, the increased cumulative total of direct investment by Korea in China is another factor of increasing China trade deficit. As the direct investment by Korea increased more rapidly, the import of raw materials and production facilities to China continuously increased and caused the acceleration of Chinese trade deficits in Sino-Korean trade. Last, The declining average tariff rate in China against the average tariff rate in Korea also had quite a strong relativity on the increase of China's trade deficit.

Based on the above causes analysis, in practice, it would be better to carry out the measures (tariff, price, anti-dumping, etc.) in all round way, thus can lead to achieve a Win-Win situation which is of mutual benefit for their sustainable economic growth..

\section{References}

C. Min Han. (Sep., 2000). Hanyang University. Korea's Direct Investments in China: Technology, Experience, and Ownership Factors in Performance, P10, P23.

Choi, Hongseok and Ann Zhongseok. (Dec., 1999). Trend of Korean Economy Due to China's FDI. Korea Institue of National Economy[Economics Essays]. Vol. 8.

Kang, Yongsoo. (2000). A historical study on the foreign trade of Korea and China. Industrial Economics Studies, Vol. 13, No. 6, Start page 579. Total page 18.

Li, Yuze. (2001). Outline of Northeast Asia Regional Economic. Jilin University Press, P164-209, P351-381.

Lin, Yangze. (1999). Asia's Economic Prospects and Challenges in the $21^{\text {st }}$ Century. China Social Sciences Press, P46-59, P141-166.

Piao, Yangchun. (1995). A Study on the Development of Sino-Korea Trade Relations During the 90's. Yanbian University Journal, P070-074.

Qi, Zhang. (Jan., 2003). Accelerator for Economic Development: findings on direct investment research among China, Japan and ROK. Intertrade.

Shi, Min. (1999). Asian-African Development Institute. Development Research Centre of the State Council. Economic Cooperation between China, Japan and Korea towards to the 21th Century. Contemporary Asia-Pacific Studies, P16-20.

Statistical Yearbook of China. (1992-2008). [Online] Available: http://www. Stats.gov.cn/tjgb/ (August 19, 2009).

Xinhua. (Sep. 5, 2001). China's WTO entry to create more investment opportunities. 
Table 1. Sino-Korean Trade Scales Since 1992

(Unit: 100 million \$)

\begin{tabular}{|c|c|c|c|c|}
\hline Year & Total Ex/Im & $\begin{array}{l}\text { China's Import } \\
\text { from Korea }\end{array}$ & Export to Korea & Trade balance \\
\hline 1992 & 63.8 & 26.5 & 37.2 & 10.7 \\
\hline 1993 & 90.8 & 51.5 & 39.3 & -12.2 \\
\hline 1994 & 116.7 & 62.0 & 54.6 & -7.4 \\
\hline 1995 & 165.5 & 91.4 & 74.0 & -17.4 \\
\hline 1996 & 199.2 & 113.8 & 85.4 & -28.4 \\
\hline 1997 & 236.9 & 135.7 & 101.2 & -34.5 \\
\hline 1998 & 184.2 & 119.4 & 64.8 & -54.6 \\
\hline 1999 & 225.5 & 136.8 & 88.7 & -48.1 \\
\hline 2000 & 312.5 & 184.6 & 127.9 & -56.6 \\
\hline 2001 & 314.9 & 181.9 & 133.0 & -48.9 \\
\hline 2002 & 411.5 & 237.5 & 174.0 & -63.5 \\
\hline 2003 & 632 & 431 & 201 & -230 \\
\hline 2004 & 900.7 & 622.5 & 278.2 & -344.3 \\
\hline 2005 & 1119 & 768 & 351 & -417 \\
\hline 2006 & 1343 & 898 & 445 & -453 \\
\hline 2007 & 1599 & 1038 & 561 & -477 \\
\hline 2008 & 1862 & 1122 & 740 & -382 \\
\hline
\end{tabular}

Source: Statistical Yearbook of China, 1992-2008.

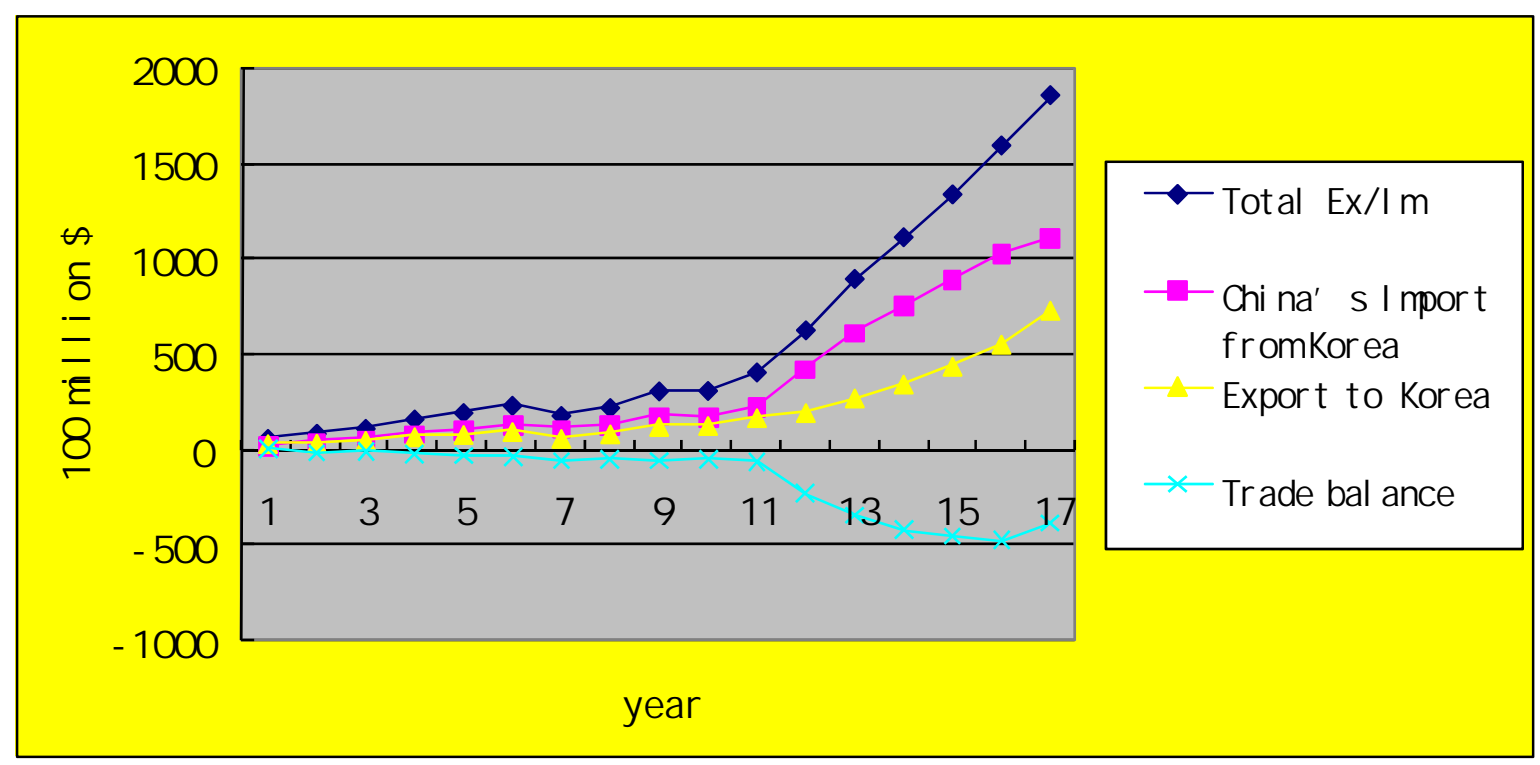

Figure 1. Change of Sino-Korean Trade Scale Since 1992 